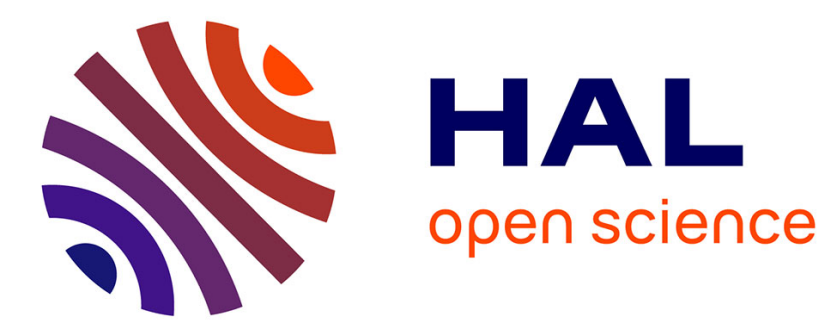

\title{
Khmer peasants and land access in Kompong Thom Province in the 1930s
}

Mathieu Guérin

\section{To cite this version:}

Mathieu Guérin. Khmer peasants and land access in Kompong Thom Province in the 1930s. Journal of Southeast Asian Studies, 2012, vol. 43 (issue 3), p. 441-462. 10.1017/S0022463412000331 . hal00725439

\section{HAL Id: hal-00725439 \\ https://hal.science/hal-00725439}

Submitted on 2 Feb 2016

HAL is a multi-disciplinary open access archive for the deposit and dissemination of scientific research documents, whether they are published or not. The documents may come from teaching and research institutions in France or abroad, or from public or private research centers.
L'archive ouverte pluridisciplinaire HAL, est destinée au dépôt et à la diffusion de documents scientifiques de niveau recherche, publiés ou non, émanant des établissements d'enseignement et de recherche français ou étrangers, des laboratoires publics ou privés. 


\section{Journal of Southeast Asian Studies}

http://journals.cambridge.org/SEA

Additional services for Journal of Southeast Asian Studies:

Email alerts: $\underline{\text { Click here }}$

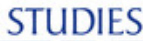

Subscriptions: Click here

Commercial reprints: Click here

Terms of use : $\underline{\text { Click here }}$

\section{Khmer peasants and land access in Kompong Thom Province in the 1930s}

Mathieu Guérin

Journal of Southeast Asian Studies / Volume 43 / Issue 03 / October 2012, pp 441 - 462

DOI: 10.1017/S0022463412000331, Published online:

Link to this article: http://journals.cambridge.org/abstract_S0022463412000331

How to cite this article:

Mathieu Guérin (2012). Khmer peasants and land access in Kompong Thom Province in the 1930s. Journal of Southeast Asian Studies,43, pp 441-462 doi:10.1017/S0022463412000331

Request Permissions : $\underline{\text { Click here }}$ 


\title{
Khmer peasants and land access in Kompong Thom Province in the 1930s
}

\author{
Mathieu Guérin
}

\begin{abstract}
Based on Cambodian and French archival records, which include colonial and local administration reports, tax rosters and judicial sources, this paper explores landownership in Cambodia in the 1930s. It shows that, contrary to common belief, land access was already an issue in the 1930s. The study of tax registers of three communes in the province of Kompong Thom presents a Khmer rural society dominated by peasants with average-sized landholdings, but where landless peasants or those with very small holdings also existed. It also stresses that women were able to become efficient farm operators. In addition, this analysis of the different sources available shows that Khmer rural society in Kompong Thom was a form of gerontocracy dominated by men aged over 40 .
\end{abstract}

It is commonly accepted that issues of land access in Cambodia are recent and that before the 1970-93 wars, Cambodian farmers could easily obtain the land they needed by clearing a patch of forest; land was plentiful and free. Fabienne Lucos, an anthropologist well known for her research on rural Cambodia, writes in the seminal Cambodge contemporain that access to land and forests 'had never been a problem in Cambodia'. ${ }^{1}$ In the social sciences, this view is largely based on the work of Jean Delvert (geographer), despite certain dissenting voices, such as Lucien Tichit (agronomist), Serge Thion or Ben Kiernan (historians), and more recently Anne Guillou (anthropologist). ${ }^{2}$ Delvert wrote the first comprehensive, multi-scalar analysis of

Mathieu Guérin is Maitre de conférences (Assistant Professor) at the Centre de Recherche en Histoire Quantitative, UMR 6583, Centre National de la Recherche Scientifique, France. Correspondence in connection with this paper should be addressed to: mathieuguerin@hotmail.com. The author would like to thank the Journal of Southeast Asian Studies for giving him the opportunity to publish this research, Ly Lan Dill who translated the original text from French, Grégory Mikaelian and Gilles de Gantès (historians), Arthur Charpentier (mathematician) and Mathilde Rieant (farmer), as well as the two anonymous reviewers whose comments helped improve this paper.

1 Fabienne Lucos, "Manger le territoire": pratiques anciennes et actuelles d'accès à la terre au Cambodge', in Cambodge contemporain, ed. Alain Forest (Bangkok and Paris: IRASEC and Les Indes savantes, 2008), pp. 419-44. This and all subsequent extended quotes in the text are translated into English from the French.

2 Lucien Tichit, L'agriculture au Cambodge (Paris: Agence de coopération culturelle et technique, 1981); Serge Thion, 'La question agraire en Indochine', Cahiers internationaux de sociologie, 54 (June 1973): 31-60; Anne Y. Guillou, 'The question of land in Cambodia: Perceptions, access, and use since de-collectivization', in 'Agriculture in Southeast Asia: An Update', special issue, Moussons, 9-10 
Cambodian peasantry, which was conducted between 1949 and 1960 . He stated that we can assume that there were few landless peasants. ${ }^{3}$ Delvert considered the problem unimportant. While generating a typology of Cambodian farmers, he emphasised their commonality and in particular the fact that the majority possessed small- to mid-sized farms. He even spoke of 'a rural democracy, rare in Asia'. ${ }^{4}$ The importance of Delvert's research explains why a half century after its publication, his work is still authoritative, even though readers accept his conclusions too quickly without necessarily rereading his entire line of reasoning.

This position is reinforced by the collective memory of Cambodian farmers as it appears in interviews with the elderly. The war years between 1970 and 1993, the genocidal Khmer Rouge regime, and the widespread land-grabbing that has accompanied Cambodia's entry into the market economy since the beginning of the 1990s, are all contributing factors to the idea of a pre-war golden age of Khmer peasantry. For example, $t a$ Khang Heng and méphum Cheung, interviewed in April 2010 in the village of Thnot Chum, believe that apart from shopkeepers, everyone possessed land before the war. ${ }^{5}$

I will apply the methods of quantitative history to available sources in order to reassess access to and ownership of land in Cambodia in the 1930s, at the apotheosis of French colonial rule. This survey studies three groups of villages in the province of Kompong Thom, which lies east of the Angkor temples, northeast of the Tonle Sap, and extends out to the Thai border. It is both at the heart of Khmer country, as defined by Delvert, and on the fringes of the Phnom Penh-Saigon axis around which was constructed the internal geopolitics of southern French Indochina. The very punctilious colonial administration established numerous archives partly based on the reports of Cambodian officials; the Kompong Thom series are relatively well preserved. These administrative, fiscal and judicial archives of Cambodia under the French protectorate call into question the image of widespread and easy access to land for all.

\section{Sources}

\section{Administrative reports}

Cambodia was a protectorate, which means that the royal Cambodian administration continued to function even as it was gradually placed under the authority and the dependency of the French colonial administration in Indochina. In the early years, the clauses of the Protectorate Treaty between France and Cambodia were broadly observed; the French intervened only marginally in the kingdom's internal affairs, except for security issues that directly concerned them. After Charles Thomson's 1884 coup, and that of Huyn de Verneville in 1897, colonial administration took over the country. ${ }^{6}$ France sent Residents to the provinces to advise the Khmer

(2006): 299-322; Ben Kiernan, 'Introduction', in Peasants and Politics in Kampuchea, 1942-1981, ed. Ben Kiernan and Chanthou Boua (London: Zed Books, 1982), pp. 1-23.

3 Jean Delvert, Le paysan cambodgien (Paris: L'Harmattan, 1994), p. 500.

4 Ibid., p. 653.

5 Interview in Thnot Chum village, Apr. 2010.

6 Milton E. Osborne, The French presence in Cochinchina and Cambodia: Rule and response (18591905) (Bangkok: White Lotus, 1997), pp. 206-30; Alain Forest, Le Cambodge et la colonisation française: Histoire d'une colonisation sans heurts (1897-1920) (Paris: L'Harmattan, 1980), pp. 59-116. 
governors, then to monitor them, before finally supplanting them. The reform of administrative jurisdictions in 1921 definitively established the Cambodian provincial administration under the authority of French Residents. Large provinces called khet were created, whose boundaries were perfectly aligned with the limits of the Residents' jurisdiction. ${ }^{7}$ The chaufaikhet (provincial governors) became, ipso facto, the Residents' native deputies. The khet were themselves divided into srok (districts), khand (district subdivisions) and khum (communes), each encompassing several phum (villages). The authorities of these jurisdictions are the sources for the archives used in the present article.

Based on information provided by the mékhum (commune head), the chaufaisrok and the chaufaikhand presented their jurisdiction's situation to the chaufaikhet every month. The latter synthesised the information in a report to the French Resident and his ranking Cambodian Minister. Using these reports along with additional information, the Resident wrote up his own analysis of his jurisdiction's political and economic situation in two new reports sent quarterly to the Résident Supérieur. These reports were standardised. The first, the 'Political Report', presented the jurisdiction's general situation, the 'spirit of the people', and any criminal acts, views on the functioning of the Cambodian administration with judicial statistics, a summary of the cash balance and tax collection, and the state of education and medical assistance. The 'Economic Report' consistently allotted a significant portion to the progress of road construction and the development of communications in general. The province's industry, trade and agriculture were then analysed as well as the doings of the Forestry Service. This was generally followed by a market report with the current prices.

Thanks to these reports, we can trace important events month by month throughout the province, sketching the outlines of economic exchanges and creating a snapshot of the daily context in which the villagers lived. However, reading them accurately requires a critical approach. All reports invariably began with a statement about the loyalty of the people and their attachment to the administration of the protectorate $-\mathrm{a}$ form of autosuggestion that in no way reflected reality. Furthermore, this statement appeared much less systematically in the Cambodian administrators' reports, which were written in Khmer. There are also the occasional discrepancies between criminal acts noted in the summary reports and those that appear in the daily correspondence, particularly during periods of high instability. It was never good for an administrator to manage a jurisdiction where order was not maintained. Even though they could not conceal all criminal acts from their supervisory authorities, if only because perpetrators could be brought before the criminal court of Phnom Penh, administrators may have minimised such deeds. ${ }^{8}$ Properly filled market reports are also extremely useful. However, because the price of rice varied greatly

7 Sorn Samnang, 'L'évolution de la société cambodgienne 1919-1939' (Ph.D. diss., University Paris VII, 1995), pp. 36-56.

8 Florian Brout, who compared criminal police records and Resident reports in the province of Kompong Chhnang between 1936 and 1940, indicated that both series are fairly consistent. Florian Brout, 'La criminalité au Cambodge (1936-1940)' (M.A. thesis, University of Caen Basse-Normandie, 2010), pp. 79-80. 
throughout the year and from one harvest to another, it is therefore suspicious when reports stated stable prices for rice and other products sold in the markets throughout the year. It is legitimate to wonder whether the author simply copied the same figures from one month to another. Only when a chaufaikhet or Resident changed can we hope to obtain more reliable data. The Résident Supérieur Silvestre, in February 1933, wrote a call to order concerning reports by the chaufaikhet:

I have the honour to draw your attention to the inadequate and sometimes inaccurate information contained in the monthly reports of certain chaufaikhets. Under the extremely important headings of Agriculture, Piracy, Personnel, most of these individuals are content to periodically copy stereotypical formulas that they do not even bother to adapt to the situation at hand.... Formulas that so utterly misrepresent the real situation clearly indicate that their users are either exaggeratedly fearful of responsibilities or lacking information to a degree that should not be seen in Cambodian officials, whose positions allow them to be informed. ${ }^{9}$

Silvestre's criticisms of the chaufaikhet's reports could well apply to those of the Residents. Notwithstanding their questionable reliability, these reports rarely allow us a glimpse into the villages. To do so, other types of sources should be privileged.

\section{Judicial sources}

Judicial sources, both civil and criminal, supply vast amounts of information on the population. The best sources are archived investigation files that present the views of both accused and prosecutors. However, like all judicial sources, they provide only a biased picture because they insist on deviances from the norm. Moreover, they are often fragmentary and serial studies are rarely possible, except for judgement extracts that accompanied the arrest warrants in Kompong Thom. A complete list is available for $1933 .{ }^{10}$

\section{Fiscal sources}

This paper focuses on the study and analysis of fiscal sources, especially the tax registers, by commune, for personal taxes, paddy taxes, and taxes on farm land. These rosters were established by the mékhum, the commune head, based on inhabitant statements.

A capitation or head tax was set at 2.5 piastres during the 1919 tax reform and applied from 1923 to all healthy males, aged 18 to 60 years old. ${ }^{11}$ Individual taxes were composed of capitation taxes, corvée redemptions, and additional hundredth taxes (centiemes). The capitation registers listed the name of the taxpayer, composed of the father's name combined with the taxpayer's name and sometimes that of his wife; his age, plus any comments. They were filed by age, starting with teenagers as young as 15 years of age. Notables headed up their registers.

9 Circular from Résident Supérieur Silvestre to Residents, 7 Feb. 1933, National Archives of Cambodia (hereafter NAC), rsc 12243.

10 NAC, rsc 14960.

11 Sorn, 'L'évolution de la société', pp. 112-13. 
The paddy tax was theoretically proportional to the harvest. Farmers declared their crops to the mékhum and were taxed 5 cents per measure or thang of paddy. ${ }^{12}$ To better verify their statements, the farmers were also required to declare the size of their fields, which were classified into five categories based on expected yields. Uncultivated paddy fields were subject to a fixed tax of 20 cents per ha. ${ }^{13}$ The paddy tax registers bore the name of the taxpayer, his wife, the surface area of cultivated rice paddies, the surface area of non-cultivated rice paddies, the amount harvested and the tax due. Lists were filed by phum and thus by geographical areas.

The tax on farm land was the former chamkar and pontea tax. This was actually a property tax whose quota was based on the size and quality of the land. ${ }^{14}$ The farm land tax register indicated the name of the landowner, his wife, the surface area, the quality of the land according to one of four established classes (see below) and the tax due. It should be noted that women did appear when they were widowed, divorced (mémay) or single (liv) and possessed a plot.

\section{The communes of Thnot Chum, Kompong Svay and Sakream}

These three registers were compared for three different communes: Thnot Chum, srok of Barai in 1930-31; Kompong Svay, srok of Kompong Svay in 1930-33; and Sakream, srok of Kompong Svay in $1932-33 .{ }^{15}$ It was thus possible to reassess each farmer's landholdings as listed on the capitation tax register and determine the commune's land distribution. This required correlating the three lists for each of the municipalities surveyed, totalling 1,593 names for Thnot Chum, 1,184 for Kompong Svay, and 1,077 names for Sakream. ${ }^{16}$ These registers listed the names of 2,381 men, the names of their wives when applicable, the names of the 238 women who owned their own land outright, and the declared surface area of 1,963 plots. During the 1931 census, the population of Kompong Thom was estimated at 159,298 inhabitants, 42,663 of whom were men aged over 18 years. ${ }^{17}$ Thus, although limited to three of the 89 communes that made up the residence of Kompong Thom, the sample includes 5 per cent of all adult males in the jurisdiction. This enabled the first large-scale approach to the question of access to land in the 1930s.

In the 1930s, the villages that made up the khum of Thnot Chum, srok of Barai, were located south of the colonial road 1bis in the province's floodplain. The village of Thnot Chum - named after the sugar palm trees dotting the landscape - was itself located roughly 10 kilometres from the road on the left bank of the Chinit River. The inhabitants practised mainly wet-rice agriculture.

12 A thang is a measure of volume: 2.5 thangs of paddy have the same mass as a picul, $60 \mathrm{~kg}$.

13 Sorn, 'L'évolution de la société', pp. 121-7.

14 Ibid., p. 135.

15 For Thnot Chum: capitation tax register, 1930; paddy tax register, 1930; and farm land tax register, 1931. For Kompong Svay: capitation tax register, 1933; paddy tax register, 1930 and 1932; and farm land tax register, 1931. For Sakream: capitation tax register, 1933; farm land tax register, 1932; and paddy tax register, 1932; NAC, rsc 12001, 12007, 12020, 12046, 12082, 12106.

16 Due to the spelling of the names written in Uksor Moul (one of the Khmer scripts), and the attendant risk of confusion between letters, the comparison was done manually and not with the help of a computer.

17 NAC, rsc 26620. 
Kompong Svay, srok Kompong Svay was about 10 kilometres northeast of the administrative centre for Kompong Thom, upstream on the Sen River, whose banks were intensively cultivated. Rice paddies extended behind the ridge. ${ }^{18}$

Sakream, khand of Sandan, was more isolated, upstream on the Sen, about 50 kilometres northeast of Kompong Thom town. The villages of the khum were established in a heavily wooded area and, although forbidden, the inhabitants practised swidden agriculture in addition to wet-rice cultivation. ${ }^{19}$

The villages in the khum of Thnot Chum and Kompong Svay appear quite representative of the Khmer lowland villages whose dwellers mostly rely on agriculture for their subsistence. We can find similar villages in Kandal, Kompong Speu and Kampot provinces. They were located not far from colonial administrative centres, which increases the reliability of the sources used, but not in daily contact with the French administrators. Sakream has the strongest connection with the forest. None of the three khum had land infringed by large-scale French concessions, nor did any of them benefit from the presence of such concessions for employment. All three study villages can be considered as being just at the margins of the space directly under the French colonial grip.

\section{The reliability of the tax registers in the 1925 survey}

The crucial question of the reliability of our sources must be raised. This is difficult to establish, since by definition tax registers do not reveal concealment, evasion and fraud. A survey conducted in 1925 by the Land Registry service sometimes showed substantial differences between the size of rice fields reported by the mékhum and those identified by land surveyors. ${ }^{20}$ The mékhum were suspected of underestimating the quality of land and crops. Thus in Kompong Thom, 'the department's investigations concerned five khums: So Yong, Chon Daung, Pongro, Barai, and Thnot Chum; in each, declarations were found to be lower by 30 to 70 per cent'. The report from the Land Registry also states 'that the rise in paddy revenue was mainly due to the classification of rice fields, performed by native authorities'. ${ }^{21}$

Cadastral surveyors differentiated each field, while the mékhum generally gave a single rate to all the plots belonging to a single owner, unless the quality of land was different, which is rare in the same communal territory. For Thnot Chum, Pongro and Barai, cadastral audits were underestimated on average by 25 per cent. For Thnot Chum, over the area of communal paddy fields surveyed, the difference between the total cultivated area declared and the paddy fields measured by cadastral surveyors was almost 15 by 48 ha (roughly 31 per cent); at Pongro it was 19.4 by 55.3 ha (35 per cent), and at Barai it was 12.3 by 57.6 ha ( 21 per cent). ${ }^{22}$

18 Fieldwork, Apr. 2010; aerial photos from the Service Géographique de l'Indochine, 1952-53 campaigns, archived at the Institut Géographique National.

19 Mathieu Guérin, 'L'administration coloniale française face à l'essartage en Indochine', in 'Terres de conquêtes, terres de déprise: Enjeux fonciers, agricoles et cynégétiques', ed. Philippe Madeline and Jean-Marc Moriceau, special issue, Enquêtes rurales, 12 (2009): 87-106.

20 NAC, rsc 18454.

21 Ibid.

22 At Chong Daung and Soyong, the land samples chosen by surveyors were drawn from a limited number of plots, with a surface area less than 9 ha. They are, therefore, not representative. 
At Thnot Chum, for the 52 plots measured by the land registry corresponding to 46 register entries, eight plots (17.4 per cent) contained measurement errors at the expense of the taxpayer. The discrepancy can easily be attributed to measurement difficulties. Maps drawn up by the Registry show that paddy fields were not perfectly rectangular. Neither the mékhum nor the Khmer peasants were necessarily versed in the art of trigonometry. The difference was also occasionally in favour of the Treasury. However, in slightly less than half the plots surveyed, the owners, with the help of the mékhum, defrauded tax authorities. Sixteen owners (34.8 per cent) reported paddy fields that were at least 20 per cent smaller than the measured surface areas - with a difference of more than 0.2 ha. Six landowners (13 per cent) underestimated the size of their paddy fields by more than 40 per cent. Thus, Sar, husband of Thong, declared 0.44 ha whereas he actually cultivated 1.6 ha of land. Finally, there were another six landowners who did not declare their rice fields at all. Thus, while data from the tax registers can be used to determine possible inequities in access to land, they do not draw an accurate map of landownership in the khum studied.

Yet the number of undeclared plots seems surprisingly low. This is not the result of the power of the mékhum, but rather that land rights were granted only when landownership was declared to the mékhum. Section 713 of the Cambodian Civil Code in force at the time stipulated that the regular payment of taxes corresponding to land was one condition for legal possession:

Art. 713. In terms of real estate, advertising possession can only result: 1 . from a statement of property made to the mékhum, who shall issue receipts when these goods have not yet been appropriated; 2 . from the regular payment of property taxes. ${ }^{23}$

Theoretically the land must be registered as stated in Article 690 of the Civil Code: ownership rights are established through land registration. ${ }^{24}$ An initial land registration campaign for the establishment of a register was launched in 1908, but was unsuccessful. In a second attempt in 1912, over 4,000 owners registered their lands in the Kompong Svay srok. Overwhelmed, the administration was unable to verify declarations or even provide enough forms. ${ }^{25}$ A 1925 decree, followed by three other declarations in 1926, 1930 and 1931, relaunched the land registration process in Cambodia, which remained largely incomplete. Despite the establishment of a corps of engineers and surveyors and the use of aerial photography, land in Thnot Chum, Sakream and Kompong Svay was still not registered by the early 1930 s. $^{26}$ Without a cadaster, the payment of taxes was necessary to prove possession of the land, which gave the holder the same rights as if he were the actual registered owner. This did not exclude fraud. It could be in a farmer's best interest to declare a smaller parcel of land than that actually cultivated and especially to declare a

23 Code civil cambodgien, d'après les travaux des commissions instituées par Arrêté des 5 juillet et 3 septembre 1912, 9 avril 1913, 19 juillet 1918 et 29 janvier 1919 (Phnom Penh: Imprimerie royale, 1951).

24 Ibid.

25 NAC, rsc 17217; Forest, Cambodge, pp. 244-53; Guillou, 'The question of land', pp. 303-5; René Morizon, L'immatriculation foncière de la propriété individuelle au Cambodge (Paris: Domat-Montchrestien, 1934), pp. 97-106; Roger Kleinpeter, Le problème foncier au Cambodge (Paris: Domat-Montchrestien, 1937).

26 Morizon, L'immatriculation foncière, pp. 137-53. 
significantly smaller harvest, a practice that was not uncommon. If harvests actually corresponded to what was declared to the tax administration, yields would have been incredibly low in Cambodia, often around $250 \mathrm{~kg} / \mathrm{ha}$, and the country would have been constantly threatened by famine. Tax registers are thus unsuitable for ascertaining the yield or even the production of paddy.

Note also that in Kompong Svay, 47 per cent of declared rice field owners do not appear in the capitation tax registers. In Thnot Chum, this figure is 52 per cent and in Sakream, 24 per cent. This could be explained either by the fact that the plots belonged to people from outside the commune, or by tax evasion. The still extant registers of the neighbouring khum were searched for the names of the plot owners as well as the capitation tax register for the province capital city. No correspondences were found. Capitation tax fraud appears to have been widespread and commonplace. Figures reach at least 26 per cent for the entire sample, with 35 per cent in Thnot Chum, 26 per cent in Kampong Svay, and 12 per cent in Sakream. We need to bear in mind that those individuals who reported nothing - neither paddy fields, nor farm land nor capitation, and thus were completely exempted from all taxes do not appear in our sources, except for those who were caught. Capitation tax, unlike paddy taxes and taxes on farm lands that guaranteed land possession, did not offer the taxpayer any significant returns, except for a card received when taxes were paid that allowed the holder to travel. This card, which villagers called the 'black card', was not issued with a photo. It was therefore possible to work out a deal with a relative or friend if necessary. In 1933, 112 men were arrested and jailed for violating the card legislation in Kompong Thom - missing cards, cards in another name, or vagrancy without a card. Those who were merely fined, the most common punishment, do not appear in the records. ${ }^{27}$

\section{Distribution of landownership}

Distribution of paddy fields

In Sakream and Thnot Chum, uncultivated paddy fields were almost never reported (Table 1). In all three khum, declarations of non-cultivated rice fields seem to primarily have been a means for an individual to reserve land. It seems wiser to settle for figures of cultivated rice fields declared to the mékhum that refer to land actually owned and used by the inhabitants. The surface areas that appear in the khum registers should not be taken as accurate and reliable. If we factor in a margin of error of 20 to 35 per cent, consistent with the results of the 1925 survey, distribution according to classes - as defined here (with a factor of two) - allows us to compensate for some of the registers' inaccuracies. However, the averages should be increased by about 25 per cent to obtain a figure that is more in keeping with the reality of the average area owned and cultivated by farmers in these khum.

The difference between average and median figures indicates that for the majority of farmers everywhere, the surface area of their rice fields was well below the average size. For the entire sample, over a quarter of landowners had less than 1 ha of cultivated rice fields. Land was classified by category. 1 ha was the minimum to adequately feed a family and generate the surplus needed to pay taxes and purchase input 
Table 1: Distribution by class of rice field surface areas, Thnot Chum, Kompong Svay, Sakream 1930-32

\begin{tabular}{|c|c|c|c|c|c|c|c|c|c|c|}
\hline & \multicolumn{2}{|c|}{ Thnot Chum } & \multicolumn{2}{|c|}{ Kompong Svay } & \multicolumn{2}{|c|}{ Sakream } & \multicolumn{2}{|c|}{ Total } & \multicolumn{2}{|c|}{$\%$} \\
\hline & $\mathbf{a}$ & b & $\mathbf{a}$ & b & a & b & $\mathbf{a}$ & b & $\mathbf{a}$ & b \\
\hline $0-0.5$ ha & 88 & 85 & 27 & 11 & 34 & 39 & 149 & 135 & 11 & 10 \\
\hline $0.5-1$ ha & 101 & 109 & 47 & 25 & 56 & 55 & 204 & 189 & 15 & 13 \\
\hline $1-2$ ha & 157 & 175 & 81 & 52 & 108 & 107 & 346 & 334 & 27 & 24 \\
\hline $2-4$ ha & 158 & 173 & 137 & 106 & 51 & 56 & 346 & 335 & 27 & 24 \\
\hline $4-8$ ha & 90 & 105 & 95 & 173 & 11 & 11 & 196 & 289 & 15 & 21 \\
\hline $8-16$ ha & 15 & 19 & 32 & 84 & 1 & 1 & 48 & 104 & 4 & 7 \\
\hline $16+$ ha & 4 & 5 & 3 & 15 & 0 & 0 & 7 & 20 & 1 & 1 \\
\hline Number of entries & 613 & 671 & 422 & 466 & 261 & 269 & 1296 & 1406 & 100 & 100 \\
\hline Total area (ha) & 1442 & 1665 & 1472 & 2588 & 419 & 452 & 3334 & 4705 & & \\
\hline Average area (ha) & 2.35 & 2.48 & 3.48 & 5.55 & 1.61 & 1.68 & 2.57 & 3.34 & & \\
\hline Median (ha) & 1.73 & 1.81 & 2.64 & 4.62 & 1.4 & 1.43 & 1.77 & 2.26 & & \\
\hline Average area in corrected figures & 2.9 & & 4.5 & & 2 & & 3.1 & & & \\
\hline
\end{tabular}

Notes: a: cultivated paddy fields in this range, as declared to the tax administration; b: sum cultivated and uncultivated paddy fields in this range, as reported to tax authorities. 
products for land in the 1st category such as in Thnot Chum. We need to keep in mind that land in the 2 nd or 3 rd categories required a larger surface area.

Important differences can be found between khum. Rice fields were thus larger in Kompong Svay, where the land was of inferior quality, with an average of 3.48 ha of cultivated rice fields declared by land users, and an actual average of roughly 4.50 ha. In Thnot Chum, the average size of cultivated fields reported in farms was 2.35 ha, with an actual average of just under 3 ha. These figures dropped to 1.61 ha in Sakream, or 2 ha with adjusted data, which is less than half the average area in Kompong Svay. However, it is likely that many rice farmers in Sakream also practised dry-rice agriculture on swidden fields, which, being illegal, was not reported, in addition to wet-rice cultivation. ${ }^{28}$ Throughout the overall sample, the most important classes were those who possessed rice fields of 1-2 ha and 2-4 ha, which represented 54 per cent of rice fields. Thus mid-size properties did indeed dominate.

Nevertheless, the importance of mid-size properties should not suggest egalitarian land distribution. The example of the Lorenz distribution curve of rice fields in Thnot Chum shows that it was far from such an ideal. The more the curve strays from the right, the less egalitarian is the distribution. In Thnot Chum, half the rice farmers shared one-fifth of the land (see Figure 1). ${ }^{29}$ For the entire sample, the average surface area of the first decile of declared rice fields is 8.65 ha or 28 times more than the lowest decile for which the average is only 0.31 ha. Micro-operators, those cultivating less than 0.5 ha, represent 12 per cent of the sample. Large properties of over 20 ha, as defined by Delvert, were extremely rare. There were officially only two for the entire sample.

\section{Distribution of farm land}

The distribution of farm land was just as unequal (Table 2). Farm land was often situated on river banks, which are particularly fertile, especially for market gardening. These plots were coveted and by definition limited - and not everyone had access to them. Farm lands of the 1st category were those dedicated to sugar cane and tobacco. The 2nd category included land planted with coffee, cotton, coconut, betel and rubber. The 3rd category was for mulberry, indigo, bananas, peanuts, sesame and intensive market crops. Other crops such as sweet potatoes, beans, soya beans, corn, squash, watermelons, cucumbers, eggplants, tomatoes, taro root, castor oil plants and fruit trees were in the 4 th category. ${ }^{30}$ The registers of all three communes showed only 560 farming plots, with only 2 in the 1 st category, 4 in the 2 nd category, 122 in the 3rd category, and 432 in the 4 th category.

The vast majority of farming plots were extremely small. A plot of 20 ares for market gardening occupied a farmer full time. In terms of work, crop value and land, there was a marked difference between an inhabitant of Thnot Chum who owned less than 5 ares of farm land in the 4th category in which he could grow a few vegetables and the Sakream farmer with 10 ares of land in the 2nd category,

28 Judicial sources reveal cases of farmers indicted by the Forestry Services for having cleared land for swidden cultivation. NAC, rsc 10006.

29 The Gini index of the distribution of cultivated rice fields in Thnot Chum is 0.26 , close to that of Kompong Svay, 0.25. In Sakream, the distribution of rice fields is significantly less unequal, with a Gini index of 0.17 .

30 Sorn, 'L'évolution de la société', p. 135. 


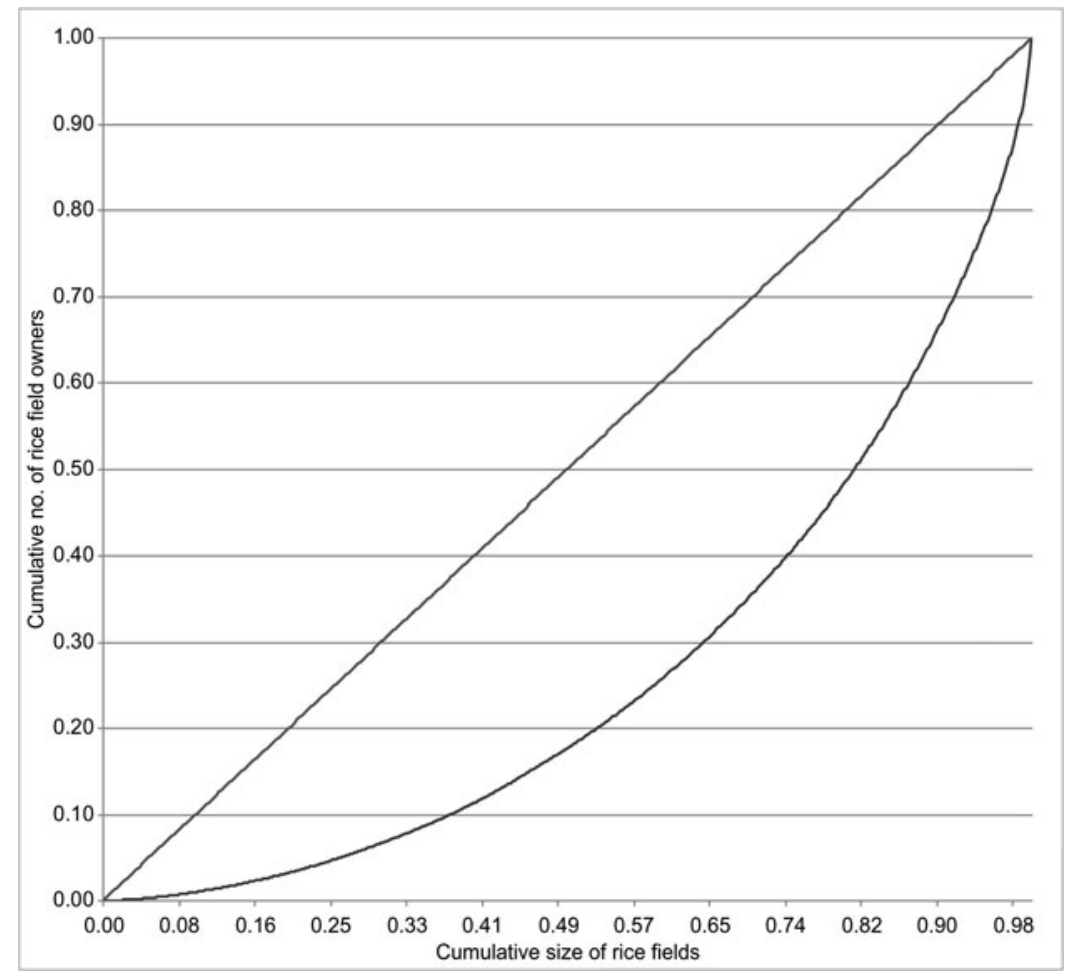

Figure 1. Lorenz curve of the distribution of cultivated rice fields in Thnot Chum (1930)

which produced high-income cash crops such as cotton, betel or coconut palms. Then there was Tong Lé, a farmer from Kompong Svay, who alone possessed 53 ares of land in the 3rd category, or 21 per cent of the available land in his commune, with its population of more than 850 men aged over 18 years old. ${ }^{31}$ The most lucrative cash crops, sugar cane and tobacco, were present only in Kompong Svay, and only on 7 ares.

\section{Landless peasants in Cambodia?}

Comparing tax registers for paddy, for farm lands, and for capitation in Kompong Svay, Thnot Chum and Sakream provides a more complete picture of land access and allows us to obtain the age of landowners. Comparing capitation, paddy, and farm land tax registers gives us the following proportion of landless individuals per khum: 335 out of 626 in Thnot Chum (54 per cent), 454 out of 659 in Kompong Svay (69 per cent), and 333 out of 538 in Sakream (62 per cent).

However, it would be misguided to consider that the share of landless was truly this high. Fraud and under-reporting must be taken into account. On the one hand, the 1925 survey shows that about 15 per cent of land was not declared and on the

31 Sum total of men aged over 18 years who paid capitation tax and those men who owned rice fields but who did not pay the capitation tax. 
Table 2: Distribution of farming land in Kompong Svay (KS), Thnot Chum (TC) and Sakream (S)

\begin{tabular}{|c|c|c|c|c|c|c|c|c|c|c|c|c|c|c|c|c|c|}
\hline & \multicolumn{4}{|c|}{ 1st category } & \multicolumn{4}{|c|}{ 2nd category } & \multicolumn{4}{|c|}{ 3rd category } & \multicolumn{4}{|c|}{ 4th category } & \multirow[b]{2}{*}{ Total } \\
\hline & KS & TC & $S$ & Total & KS & TC & $S$ & Total & KS & TC & $S$ & Total & KS & TC & $S$ & Total & \\
\hline $0-5$ ares & 2 & & & 2 & 2 & & & 2 & 43 & & 17 & 60 & 14 & 86 & 41 & 141 & 205 \\
\hline $5-10$ ares & & & & & & & 1 & 1 & 19 & & 17 & 36 & & 68 & 45 & 113 & 150 \\
\hline $10-20$ ares & & & & & & & 1 & 1 & 13 & & 9 & 22 & & 103 & 26 & 129 & 152 \\
\hline $20+$ ares & & & & & & & & & 4 & & & 4 & & 39 & 10 & 49 & 53 \\
\hline Total & 2 & 0 & 0 & 2 & 2 & 0 & 2 & 4 & 79 & 0 & 43 & 122 & 14 & 296 & 122 & 432 & 560 \\
\hline
\end{tabular}

Source: National Archives of Cambodia rsc 12020, 12046. 
other hand, between 25 and 50 per cent of male landowners did not appear in the capitation tax registers. If we take into account capitation tax fraud as revealed through comparing the paddy and capitation tax registers and the non-declaration of land as estimated following the 1925 survey, we obtain adjusted data: 25 per cent of peasants in Thnot Chum were landless, 44 per cent in Kampong Svay, and 49 per cent in Sakream. This estimate is on the low side because landless individuals who did not pay capitation do not appear, even though we know they exist, notably through court records when they were arrested. However, all landowners are accounted for, as well as fraud as estimated by the Land Registry. It is possible to take into account these corrected elements of register data in terms of the age range of landless villagers.

There is a strong correlation between age and land access: as peasants grew older, their access to land increased (Table 3). It seems logical that those under 20 years of age almost never owned land because they still lived with their parents; throughout the three khum, only 3 per cent of this segment were landowners. Access to land tenure appeared at a relatively late age. It is only within the 25-29 years age group that the majority of villagers listed in capitation registers owned land, be it rice fields and/or farm land. In Kompong Svay and Sakream, men had to wait until they were 30 to 34 years old before the majority of them owned land. It seems that in most cases, farmers had to wait for the death of their parents before owning their own land, which made inheritance the most common mode of land transfer. ${ }^{32}$

Tax fraud does not fundamentally call into question the conclusions of the comparative study of registers. The proportion of landless villagers remains important. A significant proportion of men under 30 years of age did not own land; nonetheless, this does not mean that they lacked access to land, for they could cultivate their parents' land. Nevertheless, a significant proportion of the population never owned tenured land. Throughout the three khum, at least 20 per cent of men aged over 35 years - one in five - did not own land (Table 3). Thnot Chum is quite different from the two other khum; there, only 12 per cent of men did not own land. ${ }^{33}$ As the peasants advanced in age, the death of their parents became ever more likely, thereby invalidating the idea that this older group continued to cultivate their parents' land. Some were not farmers, but rather craftsmen, fishermen or shopkeepers, but they were only a small proportion of the landless villagers in the study areas, however. ${ }^{34}$ Fishermen or merchants would have needed boats and these were rare:

32 This coincides with May Ebihara and Gabrielle Martel's observations in the late 1950s and early 1960s in Svay, Kandal Province, and Lovea, Siem Reap Province. May Mayko Ebihara, 'Svay, a Khmer Village in Cambodia' (Ph.D. diss., Columbia University, New York, 1968), p. 219; Gabrielle Martel, Lovéa, village des environs d'Angkor: Aspects démographiques, économiques et sociologiques du monde rural cambodgien dans la province de Siem Réap (Paris: EFEO, 1975), p. 142.

33 For a recent comparison, the special representative of the Secretary-General of the United Nations Commissioner for Human Rights in Cambodia, Peter Leuprecht, stated that the percentage of landless peasants was difficult to determine and cited studies that estimated the number to be between 12 and 15 per cent. Peter Leuprecht, 'Land concessions for economic purposes in Cambodia: A human rights perspective' (Phnom Penh: Office of the United Nations High Commissioner for Human Rights, Nov. 2004).

34 Buddhist monks and militiamen, around 10 per cent of the adult male population nationally, were not required to pay capitation taxes, and therefore did not appear in the personal tax registers. They would appear in our sources only if they owned land. 
Table 3: Population and the landless: Distribution of landowners based on capitation registers per age range, with corrected data

\begin{tabular}{|c|c|c|c|c|c|c|c|c|c|c|}
\hline \multirow[b]{2}{*}{$\begin{array}{l}\text { Age range } \\
\text { (years) }\end{array}$} & \multicolumn{3}{|c|}{ Thnot Chum } & \multicolumn{3}{|c|}{ Kompong Svay } & \multicolumn{3}{|c|}{ Sakream } & \multirow{2}{*}{$\begin{array}{c}\text { Overall } \\
\text { Landless } \\
\%\end{array}$} \\
\hline & Population & $\begin{array}{c}\text { Landless } \\
\text { no. }\end{array}$ & $\begin{array}{c}\text { Landless } \\
\%\end{array}$ & Population & $\begin{array}{c}\text { Landless } \\
\text { no. }\end{array}$ & $\begin{array}{c}\text { Landless } \\
\%\end{array}$ & Population & $\begin{array}{c}\text { Landless } \\
\text { no. }\end{array}$ & $\begin{array}{c}\text { Landless } \\
\%\end{array}$ & \\
\hline $15-19$ & 69 & 64 & 93 & 59 & 59 & 100 & 95 & 94 & 99 & 97 \\
\hline $20-24$ & 192 & 72 & 37 & 200 & 118 & 59 & 70 & 48 & 69 & 52 \\
\hline $25-29$ & 66 & 16 & 24 & 122 & 68 & 56 & 101 & 55 & 54 & 48 \\
\hline $30-34$ & 111 & 29 & 26 & 97 & 47 & 48 & 60 & 25 & 42 & 38 \\
\hline $35-39$ & 114 & 23 & 20 & 88 & 24 & 27 & 69 & 20 & 29 & 25 \\
\hline $40-44$ & 89 & 9 & 10 & 72 & 23 & 32 & 57 & 12 & 21 & 20 \\
\hline $45-49$ & 89 & 11 & 12 & 57 & 11 & 19 & 52 & 15 & 29 & 19 \\
\hline $50-54$ & 59 & 6 & 10 & 46 & 12 & 26 & 35 & 6 & 17 & 17 \\
\hline $55-59$ & 50 & 3 & 6 & 44 & 12 & 27 & 32 & 8 & 25 & 18 \\
\hline $60-64$ & 41 & 7 & 17 & 41 & 7 & 17 & 8 & 3 & 37 & 19 \\
\hline $65-69$ & 25 & 2 & 8 & 36 & 3 & 8 & 17 & 5 & 29 & 13 \\
\hline $70-74$ & 34 & 3 & 9 & 16 & 6 & 37 & 4 & 1 & 25 & 19 \\
\hline $75+$ & 0 & 0 & 0 & 1 & 0 & 0 & 2 & 1 & 50 & 33 \\
\hline Total & 939 & 245 & 26 & 879 & 390 & 49 & 602 & 293 & 49 & 38 \\
\hline
\end{tabular}


there were 5 in Thnot Chum and 11 in Kompong Svay, 80 per cent of which belonged to ethnic Chinese. Sakream is too far upstream. ${ }^{35}$

\section{The landless in rural Cambodian society}

\section{Vagrancy}

There was therefore a class of landless peasants in Cambodia in the 1930s made up of men asked to work land that did not belong to them and which would not belong to them at the death of the rightful owners. These land labourers also appear in court records when they were arrested for vagrancy due to a lack of employment. Thus, in 1933, 105 men were imprisoned in the residential jurisdiction of Kompong Thom for 'vagrancy without a card'; they made up one-third of all imprisonments. The Cambodian penal code of 1924, inspired by the French penal code, considered vagrancy a crime against public order.

Art. 362. All males over the age of eighteen and under sixty years, physically and mentally sound, who are not normally engaged in any work and who can not justify an avowable means of existence either are considered to be in a state of vagrancy and can therefore be punished with a prison sentence of one month to one year. Women, under the same conditions of age and physical ability, risk the same sentences if they engage in public begging. ${ }^{36}$

All men arrested for vagrancy were listed in the prison registers under 'no occupation'. Vagrants aggravated their cases if they did not show their tax cards. ${ }^{37}$ Among the nine vagrants from Kompong Svay and Sakream imprisoned in 1933, ${ }^{38}$ only one was also listed in the capitation tax registers, identified by his name and that of his wife: Pech Mean, 26 years old, married.

More surprisingly, two of the nine appeared in the tax registers for paddy and farm land in Sakream: in 1932, Prom Thlok, 33, married, owned 2.60 ha of rice fields and the same year, Suon Mey, 51, married, owned 60 ares of rice fields and 4.40 ares of 4 th-category farm land. How could married men, living in their home communities and thus involved in village society, and more importantly landowners, be considered unemployed, arrested, brought before a court, and sentenced on charges of vagrancy? The most likely explanation is that these men borrowed against their lands and lost them when they were unable to repay. In Kompong Thom, harvests were at best mediocre and at worst disastrous in 1928. They were good in 1929, 1930 and 1931, and average in 1932. The plight of these farmers arrested in 1933 had less to do with a poor harvest than with the state of the market due to the impact of the Great Depression in French Indochina. By 1931, the Kompong Thom chaufaikhet indicated that farmers were struggling to sell their crops for lack of outside buyers. ${ }^{39}$ Prices fell slightly, but remained relatively steady until the sale of the 1931 harvest at the

35 River boat registry 1932, NAC, rsc 12198.

36 Code pénal promulgué par ordonnance royale du 25 août 1924, modifié par ordonnance royale du 16 mai 1929 (Phnom Penh: Imprimerie du gouvernement, 1929), p. 78.

37 Ibid., Article 365.

38 None came from Thnot Chum.

39 Kiernan quotes Hou Yuon who emphasised that 'the crucial problem was whether there would be a buyer or not'. Kiernan and Boua, Peasants and Politics, p. 11. 
beginning of 1932. A picul of first-quality paddy dropped from 2.65 piastres before the crisis to 80 cents per picul in January 1932, before rising slightly above 1 piastre per picul. The following year, the crop was once again sold for 90 cents per picul. ${ }^{40}$ In 1930, one had to sell three piculs of paddy in order to pay personal taxes (capitation, corvée redemptions, additional centièmes). In 1932, eight piculs had to be sold, or one-third of the harvest of 1 ha of average rice fields in both 1932 and 1933 to pay for the personal tax for the head of the household alone. Many could not pay and started borrowing as early as 1932. Their land was seized the following year and they lost its use, thereby joining the ranks of landless vagrants in the eyes of the colonial administration. ${ }^{41}$

Thus, 57 per cent of men arrested for vagrancy without their tax cards were living in their home communes and were married. The marginalisation of these peasants seems to be more the result of repressive policies by French colonial authorities than the functioning of Cambodian village society. Indeed, the landless were needed to work the fields of the largest or older landowners. They were thus integrated into networks of village and family solidarity. We are far from the image of the vagabond wandering the roads. In 1933, only 14 out of the 105 men imprisoned on charges of vagrancy in Kompong Thom came from elsewhere in Cambodia and could therefore fit this last description. Beyond the conjunctural aspects of the 1930 crisis, the fact that those who lost their land could not justify a means of existence the following year shows that it was not enough to simply clear a section of forest and settle as a farmer. Land access was indeed a problem.

\section{Acknowledging the existence of landless peasants}

Court records corroborate information obtained by comparing various tax registers. Landless peasants did exist and they were increasingly pursued by the authorities. Their existence was long denied because of the myth that land was available for everyone. The denial could be explained by our understanding of pre-colonial modalities of landownership. The land belonged to the king and the people could use it by clearing a bit of the forest. As long as there was land left to be cleared, everyone could create his own plot.

This model led to an underestimation of the concept of land possession and its consequences in terms of limiting access to land for all and the possibility of litigation around land issues. ${ }^{42}$ The introduction of Crown land and private landownership by the French in 1884 resulted in designating a possessor and an owner for all the land in Cambodia. To acquire private land, you had to buy it. Crown lands could not be appropriated by individuals until they had placed a request for permission to clear forest land or for a concession if the plot exceeded 10 ha. This required weighty

40 Trimesterial economic report from the Resident of Kompong Thom, 4th trimester 1928, 1st trimester 1931, Archives nationales d'outre-mer (hereafter ANOM) (hereafter ANOM), rsc 417 et 418; monthly reports from the chaufaikhet of Kompong Thom, 1929-1933, NAC, rsc 12242, 12243, 12245. 41 Hou Yuon described comparable mechanisms in 1955, also observed by Martel during her fieldwork in the village of Lovea, Siem Reap, in 1961-62. Hou Yuon, 'The peasantry of Kampuchea: Colonialism and modernization', in Peasants and Politics, ed. Kiernan and Boua, pp. 37-8; Martel, Lovéa, pp. 140-2. 42 Adeline Carrier, 'Propriété versus possession: L'urbanisation différenciée de Phnom Penh au regard de la réforme foncière (1863-1953)', Péninsule, 59, 2 (2009): 93-142. 
administrative procedures that could take several months. Up until the end of 1928, only 2,211 'Indigenous concessions' had been granted, covering less than 36,000 ha across Cambodia. ${ }^{43}$

Where population densities were high, as in Kompong Svay or Thnot Chum, no land was available for those looking to settle down. In a context of demographic growth, as was the case in Cambodia at the beginning of the twentieth century, this meant that many farmers had to share and thus break up existing plots, or to settle for land that was either far away or of poor quality. Their only other choice was to offer their labour to those who might need it. Thus, for 1930, we diverge from Delvert who tended to underestimate the "proportion of field "proletarians"'44 or from Lucos when she considers that Cambodia's agrarian problem appeared in the post-war era. In his 1969 study, published in 1981, Tichit had already noted that it is customary to say that there is no land problem in Cambodia. In reality, land disputes are fairly numerous, and it would be fairer to say that there has yet to be acute agrarian problems. ${ }^{35}$ Delvert's conclusions are even more intriguing in that within his large-scale examples he unveils a segment of landless peasants. ${ }^{46}$ In the early 1960s, Delvert was writing amidst growing Communist dissent in Cambodia. He sought above all to deny the existence of a class of landless peasants as understood in a Marxist context.

\section{Marriage and landownership}

There is a strong correlation in the registers between the percentage of married people and the percentage of people with access to land (Table 4). ${ }^{47} \mathrm{~A}$ more detailed study of the sample shows that marriage is not a condition for land access, except perhaps in Sakream where there is only one unmarried man declared as owning a rice field. The opposite is true; land possession is not a requirement for marriage. Thus in Thnot Chum, 52 single men declared owning a rice field, whereas 116 married and 7 widowed men did not report any. In Kompong Svay, the figures are, respectively, 32, 130 and 13; and in Sakream 1,115 and 5. It would seem that marriage facilitated access to land tenure for men, which because of the late age at marriage, explains the need to wait quite some time before owning land. However, our sources do not allow us to delve further in this analysis.

\section{Women farm operators}

In the three communes covered by this study, women who possessed land were declared farm operators generally when they were widowed or divorced, and, in rare circumstances, single. They owned 11 per cent of rice fields that covered 7 per cent of

43 Eugène Teston and Maurice Percheron, L'Indochine moderne: Encyclopédie administrative, touristique, artistique et économique (Paris: Librairie de France, 1931), p. 895.

44 Delvert, Le paysan cambodgien, p. 501.

45 Tichit, L'agriculture, p. 49.

46 Thus in Trapeang Krasang, in the central provinces, Delvert counted 77 landless peasants, or 10 per cent of peasants. He estimated that there were even more in the southeastern provinces. For Kompong Thom, he cited the examples of khum with large populations of day labourers, sharecropping tenants and tenant farmers. Delvert, Le paysan cambodgien, pp. 544, 579, 620.

47 Correlation rates between both series are 0.87 in Thnot Chum, 0.89 in Kompong Svay and 0.94 in Sakream. 
Table 4: Marriage and landownership (rice fields and farm land) of men listed in the capitation tax registers (corrected data)

\begin{tabular}{|c|c|c|c|c|c|c|c|c|c|}
\hline \multirow[b]{2}{*}{ Age range (years) } & \multicolumn{3}{|c|}{ Thnot Chum } & \multicolumn{3}{|c|}{ Kompong Svay } & \multicolumn{3}{|c|}{ Sakream } \\
\hline & no. & Married (\%) & Landless (\%) & no. & Married (\%) & Landless (\%) & no. & Married (\%) & Landless (\%) \\
\hline 15-19 & 69 & 0 & 93 & 59 & 0 & 100 & 95 & 0 & 99 \\
\hline $20-24$ & 192 & 11 & 37 & 200 & 7 & 59 & 70 & 20 & 69 \\
\hline $25-29$ & 66 & 45 & 24 & 122 & 28 & 56 & 101 & 56 & 54 \\
\hline $30-34$ & 111 & 68 & 26 & 97 & 54 & 48 & 60 & 85 & 42 \\
\hline $35-39$ & 114 & 81 & 20 & 88 & 75 & 27 & 69 & 85 & 29 \\
\hline $40-44$ & 89 & 89 & 10 & 72 & 85 & 32 & 57 & 84 & 21 \\
\hline $45-49$ & 89 & 98 & 12 & 57 & 95 & 19 & 52 & 91 & 29 \\
\hline $50-54$ & 59 & 95 & 10 & 46 & 85 & 26 & 35 & 93 & 17 \\
\hline 55-59 & 50 & 97 & 6 & 44 & 88 & 27 & 32 & 89 & 25 \\
\hline $60-64$ & 41 & 88 & 17 & 41 & 84 & 17 & 8 & 58 & 37 \\
\hline $65-69$ & 25 & 81 & 8 & 36 & 84 & 8 & 17 & 87 & 29 \\
\hline $70-74$ & 34 & 82 & 9 & 16 & 92 & 37 & 4 & 75 & 25 \\
\hline $75+$ & 0 & 0 & 0 & 1 & 100 & 0 & 2 & 50 & 50 \\
\hline
\end{tabular}

Sources: National Archives of Cambodia rsc 12001, 12007, 12020, 12046, 12082, 12106. 
the cultivated surface area. Their rice fields were rather small, with a reported average area of 2.17 ha. Women were particularly represented as owners of farm lands, which can perhaps be explained by the fact that these lands provided the best crop value for labour invested. One out of every six farm owners was a lone woman, and they controlled one-sixth of farm lands.

Far from the image of the abandoned, divorced woman or the wretched widow, certain women appear to have truly run their farms. Nineteen women declared they cultivated over 4 ha of rice fields. One of them, Ouch Neang in Kompong Svay, declared 8.69 ha. It is impossible for one person to operate such vast areas, even with the help of children. These women therefore had dependants, either workers paying off incurred debts or employees, who helped with farming tasks. We should mention that one of them, neang Huy Neang, owned 4 ares out of the total sample of 7 ares of 1st-class land and that of the three plots of over 50 ares designated for market crops that appear in our sample, two were owned by widows or divorcees, neang Hem and neang Von from Thnot Chum.

\section{The different categories of farmers}

The study of the tax registers of these three Cambodian communes leads to a profound relativisation of the concept of 'rural democracy' while allowing the creation of a typology of Cambodian farmers in Kompong Thom.

\section{Peasants with average landholdings}

The main group is indeed made up of average landholders, peasants with 1 to 4 ha of rice fields, such as Khet $\mathrm{Mi}, 32$ years old, husband to neang Ok, who declared 1.62 ha in Thnot Chum. They also often have plots of farm land such as Khlang Plang, 36 years old, husband to neang Tès, in the same khum who declared 1.66 ha of paddy fields and 4 ares of farm lands. They represent 54 per cent of the sample.

\section{Affluent peasants}

Then there were affluent peasants who had between 4 and 20 ha of paddy fields, among whom were several unmarried women. In Thnot Chum, we have the example of Prak Men, 61 years old, married to neang Rot who operated 10.35 ha of rice fields and 28 ares of farm land; or Prom Chan, 48 years old, married to Nim, who had 7.18 ha of rice fields and 21 ares of farm land. ${ }^{48}$ In Kompong Svay, the chumtup Vean, 48 years old, married to neang Ma, declared 9.62 ha of cultivated rice fields; Hing Doung, 61 years old, married to neang Cham, had 11.44 ha of rice fields and 8 ares for cash crops; Srey Sam, 37 years old, married to neang Sar, operated 17.50 ha. ${ }^{49}$ There were decidedly fewer such affluent peasants in Sakream, although there was Mau Shush, 34 years old, married to neang San, who declared 8.8 ha of wet-rice fields. ${ }^{50}$ The main difference between these affluent peasants and their average counterparts is that the

48 Nos. 255, 321, 536 and 455, 1930 personal tax register; nos. 207, 176 and 58, 1930 paddy tax register; nos. 381, 276, 60 and 119; 1931 farm land tax register, Thnot Chum, NAC, rsc 12082, 12001, 12020.

49 Nos. 6, 377 and 554, 1933 personal tax register; nos. 324, 351 and 414, 1930 paddy tax register; nos. 2, 19, farm land tax register, Kompong Svay, NAC, rsc 12001, 12020, 12106.

50 No. 282, 1933 personal tax register; no. 198, 1932 paddy tax register, Sakream, NAC, rsc 12007, 12106. 
former could not cultivate their farms alone or with their family. They had dependants, labourers working off incurred debts, or employees to help them.

\section{Landlords}

Large landowners cultivating over 20 ha were very rare. There were officially only two in Thnot Chum: Ma Oun, 57 years old, married to neang Sar, who declared 28.59 ha of cultivated land and 11 ares for cash crops; and Soeur who declared 24 ha. However, it is very likely that others existed, notably among those who reported between 10 and 20 ha, even though they possessed much more, including land withheld for debts incurred, which were not yet officially theirs even if they were already cultivating it. It should be noted that many of these landowners do not appear on the registers of personal tax. They were thus not subject to corvée or capitation. This is the case of Soeur in Thnot Chum who operated 24 ha of rice fields. He was not taxed for his cultivated rice fields either, for their production was declared nil in 1930. Such fraud was impossible without the help of authorities.

One might also note that large areas were reserved by farmers through the payment of tax on non-cultivated rice fields. This is particularly true in Kompong Svay where the demand for land was great. For example, Tit Lung, 62 years old, married to neang Him, declared 33.85 ha, of which 9.24 ha were cultivated in 1930, and only 6.24 ha two years later. ${ }^{51}$ It is unlikely that the decrease in surface area was due to his age. In 1930, at 62 years old, he was not tilling and reaping with a sickle over 9 ha of rice fields. Rather, the decrease in cultivated areas was a response to the economic crisis and shrinking market outlets. Tit Lung maintained land and paid the incumbent tax to secure the family holdings, either in hopes of better days or to bequeath them to his children. The fact that he could reduce the cultivated acreage while paying taxes on all his land shows that he was relatively well off, which is markedly different from the poor farmers who constitute the last group.

\section{Poor peasants and labourers}

This group of poor peasants includes all those who owned less than 1 ha of rice fields. It was difficult for them to produce surpluses for the market and yet they had to pay their taxes in currency. The owners of paddy fields under 50 ares, those who had just a few ares of fertile farm land, and landless heads of households represented about one-third of our sample, once data have been duly corrected. They formed a particularly vulnerable group. They were the ones listed in the prison registers after convictions for vagrancy. They were the first victims of the crisis of the 1930s, especially since the crime of vagrancy led to a criminalisation of poverty. Some cases were dramatic. Thus, So Sam, 49 years old, married, from the village of Triel, southeast of Kompong Thom, was arrested in his village on 1 February 1933 for vagrancy without a tax card and sentenced to two months' imprisonment. Considered a repeat offender in August, five months after his release, he received a further four-month prison sentence and was fined 4.70 piastres. $^{52}$

51 No. 577, 1933 personal tax register; no. 183, 1930 paddy tax register; no. 195, 1932 paddy tax register, Kompong Svay, NAC, rsc 12001, 12007, 12106.

52 Prison warrants nos. 150 and 327, 1933, NAC, rsc 14960. 
Despite this, there are no traces anywhere of a class of field proletarians sufficiently class-conscious to use the Marxist concepts that would justify the doxa of the Khmer Rouge and their supporters starting in the 1950s. Poor Cambodian farmers were integrated into the social organisation of their village..$^{53}$ In terms of identity, they were first and foremost members of a family, then a phum, before taking on the label of 'poor peasant'. In this sense, landless Cambodians were very different from Italian braccianti or Spanish braceros during the inter-war period.

As James Scott pointed out for Vietnam and Burma in the same period, the very precarious situation of poor peasants worsened under three factors: 'demographic change, production for the market, and the growth of the state. ${ }^{54}$ In Cambodia, differences in social stratification, land access and tax pressure did not lead to violent forms of rebellion similar to that studied by Scott. However, if we have no evidence of social unrest, this does not mean that peasants did not resist. The large-scale tax evasion evident in the records, for example, was a form of resistance against the state. ${ }^{55}$

\section{An accepted gerontocracy}

Beyond the differences between social groups of farmers related to access to land, the village society model that appeared in the tax registers of the Cambodia province of Kompong Thom in the 1930s appears to be dominated by those over 40 years old, particularly men between 40 and 60 years old. Over 90 per cent of them were married as compared with 43 per cent of men between 25 and 29 years old. Landownership reached 80 per cent for the former and only 52 per cent for the latter group. The older men had more farm land than the younger ones and their rice fields were more extensive. It is no coincidence that almost all wealthy farmers could be found in this older age group; 88 per cent of notables - mékhum, chumtup, kromchumnum - were between 40 and 59 years old. The youngest commune councillor, the kromchumnum Het from Sakream, was an exception, being only 28 years old. Even the 65- to 69-year-olds were twice as likely to have a spouse than those aged 25-29 years. They also possessed more land, which was worked by younger men. Cambodian farmers achieved economic independence belatedly ${ }^{56}$ and thus acquired the possibility of founding a family relatively late. The fact that there were three to four times more widows than widowers in the registers, despite high maternal mortality rates, could indicate that men did indeed tend to marry late, but with younger women. ${ }^{57}$ Within village society, men over 40 years old had the greatest

53 Unfortunately, the sources do not enable a precise identification of sharecropping tenants, tenant farmers and labourers, even if later studies show that the three categories existed. Hou Yuon, 'The peasantry of Kampuchea', pp. 29-86; Ebihara, 'Svay', p. 220; Delvert, Le paysan cambodgien.

54 James C. Scott, The moral economy of the peasant: Rebellion and subsistence in Southeast Asia (New Haven and London: Yale University Press, 1976), p. 196.

55 In his 1976 study, James Scott focused on the grip of the state, moneylenders and landlords to explain why and how peasants went into revolt. For the sake of his argument, he considered the power of the colonial state as overwhelming, diminishing the importance of tax evasion and other forms of non-violent resistance. Ibid.

56 See Martel, Lovéa, pp. 208-9.

57 Tax registers for paddy and farm land. It is also possible that widowers remarried more easily than widows. For more information on age differences at marriage, see Jacques Népote, Parenté et organisation sociale dans le Cambodge moderne et contemporain, quelques aspects et quelques applications du modèle les régissant (Geneva: Olizane and Cedorek, 1992), pp. 135-8. 
access to land, to honours, to power, and even to women. They tended to hold on to these as long as they could, creating a de facto gerontocracy, a system dominated by the older men.

This system of domination by the elders seems well implanted and does not appear to have given rise to tension between generations. The Kompong Thom court records for the period make no mention of intergenerational conflict. Thierry Bouhours, criminologist, found only 100 cases of violence against older family members between 1927 and 1940 for the entire kingdom, which is less than eight per year. ${ }^{58}$ This can be explained by the importance of the family in Cambodian society. ${ }^{59}$ It was not until the Khmer Rouge regime in the 1970s, whose leader Pol Pot came from Kompong Thom, that an institutionalised mistrust of elders by youths was established as part of the revolution.

\section{Beyond Thnot Chum, Kompong Svay and Sakream}

The findings of our study extend much further than the three khum here. In order to verify our main conclusions, we consulted prison registers and court records concerning the entire jurisdiction of Kompong Thom along with the available tax registers for ten khum: Sambor (Kompong Svay), Promtep (Kompong Svay), Pongro (Kompong Svay), So Yong (Kompong Svay), Choeu Teal (Kompong Svay), Trapeang Russey (Kompong Svay), Barai (Barai), Chralong (Barai), Chong Daung (Barai) and Triel (Barai). ${ }^{60}$

Here there were mostly small- and mid-sized farms. Large farms were concentrated in a few khum such as Trapeang Russey or Barai. In the latter, a farmer named Teav Meng Si, husband to neang Chrouk, declared 49.65 ha of cultivated rice fields. Unequal land distribution was therefore far from exceptional. The norm throughout was an elevated average age at marriage between 25 and 35 years old, depending on the khum. However, the characteristics of this study's particular model of ties to the land should not be generalised too quickly to all of Cambodia, even if our findings are consistent with the study conducted by Yves Henry at the national level in $1930,{ }^{61}$ or to other periods.

At this stage, it should not be assumed that unequal distribution of land and its social consequences also existed in pre-colonial Cambodia. The situation in the 1930s could have been the result of French rule over Cambodia and French Indochina. The extremely informative archives produced by Khmer and French governments between 1863 and 1953 need to be reconsidered critically so that historical studies on Cambodian society can shake free from preconceived ideas, many of which are rooted in colonial literature or works branded with the seal of Marxism or anti-Marxism.

58 Based on the archives of the Cambodian judicial services and the Annuaire statistique de l'Indochine, ANOM; Personal communication, June 2010.

59 Népote, Parenté et organisation sociale, p. 37.

60 NAC, rsc 12001, 12020, 12007, 12046, 12082, 12083, 12106.

61 Yves Henry, L'économie agricole de l'Indochine (Hanoi: Imprimerie d'Extrême-Orient, 1932), quoted in Kiernan and Boua, Peasants and Politics, pp. 6, 34, 57, 72-4. 